\title{
Early Christianity in East Africa and Red Sea/Indian Ocean Commerce
}

\section{Les débuts du Christianisme en Afrique de l'est et le commerce de la mer Rouge et de l'Océan Indien}

\author{
Eivind Heldaas Seland
}

Published online: 18 November 2014

C The Author(s) 2014. This article is published with open access at Springerlink.com

\begin{abstract}
The ancient East African kingdom of Aksum gradually adopted Christianity from the early- to mid-fourth-century reign of Ezana onwards. The well-known narrative of the late Roman church-historian Rufinus relates a top-down process of conversion, starting with the ruler himself. The report, corroborated by the adoption of Christian symbolism on Ezana's late coinage, and monotheistic as well as overtly Christian references in royal inscriptions, is generally considered trustworthy. While not challenging the significance of charismatic and powerful individuals, this article argues that Christianity was present in the region before Ezana, and that the introduction of Christianity should be situated within the context of early Red Sea/Indian Ocean commerce. Trade was the carrier of ideological impulses from communities in the Indian Ocean and Mediterranean worlds and created the social infrastructure that expatriate believers, early converts, and later, church officials and local elites could draw upon.
\end{abstract}

Résumé Durant le règne d'Ezana, dans la première partie du quatrième siècle ap. J.-C., l'ancien royaume Aksoumite adopta le Christianisme comme religion d'état. Le récit bien connu de l'historien ecclésiastique tardif Rufinus décrit un processus de conversion du sommet à la base, débutant par le monarque en personne. Ce compte-rendu est généralement accepté comme fiable, d'autant plus que l'adoption de symboles chrétiens des monnaies tardives d'Ezana lui apporte soutien. Ne remettant pas en cause le rôle de personnages charismatiques et puissants dans la dissémination du Christianisme, cet article propose néanmoins que le Christianisme existait déjà dans la région avant le règne d'Ezana, et que son introduction serait plutôt à replacer dans un contexte antécédent du commerce de la mer Rouge et de l'Océan Indien. Le commerce était un important véhicule d'impulsion idéologique émanant des communités de la

E. H. Seland $(\bowtie)$

Department of Archaeology, History, Cultural Studies and Religion, University of Bergen, Bergen, Norway

e-mail: eivind.seland@ahkr.uib.no 
Méditerranée et de l'Océan Indien, et créa un réseau social sur lequel les croyants expatriés, les nouveaux convertis, et plus tard les représentants de l'Église et les élites locales pouvaient s'appuyer.

Keywords Aksum $\cdot$ Christianity. Trade $\cdot$ Red Sea $\cdot$ Indian Ocean $\cdot$ Trade diasporas $\cdot$ Social networks

\section{Introduction}

The Aksumite polity was centered on the present-day city of Aksum in northern Ethiopia (Fig. 1). Modern scholarship is divided on the extent and chronology of Aksumite territorial domination. In the period discussed here, however, the fourth century $\mathrm{CE}$, the core territory of the kingdom incorporated the area from Adulis on the Bay of Zula and into the highlands on both sides of the border between present-day Eritrea and Ethiopia. In periods, some degree of Aksumite rule seems to have included a substantially larger region, possibly the coast from present-day Sudan to Djibouti, along with larger parts of northern Ethiopia, southern Sudan, and Eritrea, as well as parts of modern Yemen (Munro-Hay 1991; Phillipson 2012; Bowersock 2013), but the exact nature and extent of Aksumite control outside the core region are hard to establish.

The kings of Aksum adopted Christianity ca. CE 330-340 (Conti Rossini 1928; Kaplan 1982, 2004; Munro-Hay and Juel-Jensen 1995; Haas 2008; Phillipson 2012), the kingdom thus being among the very first polities to officially embrace the faith. By

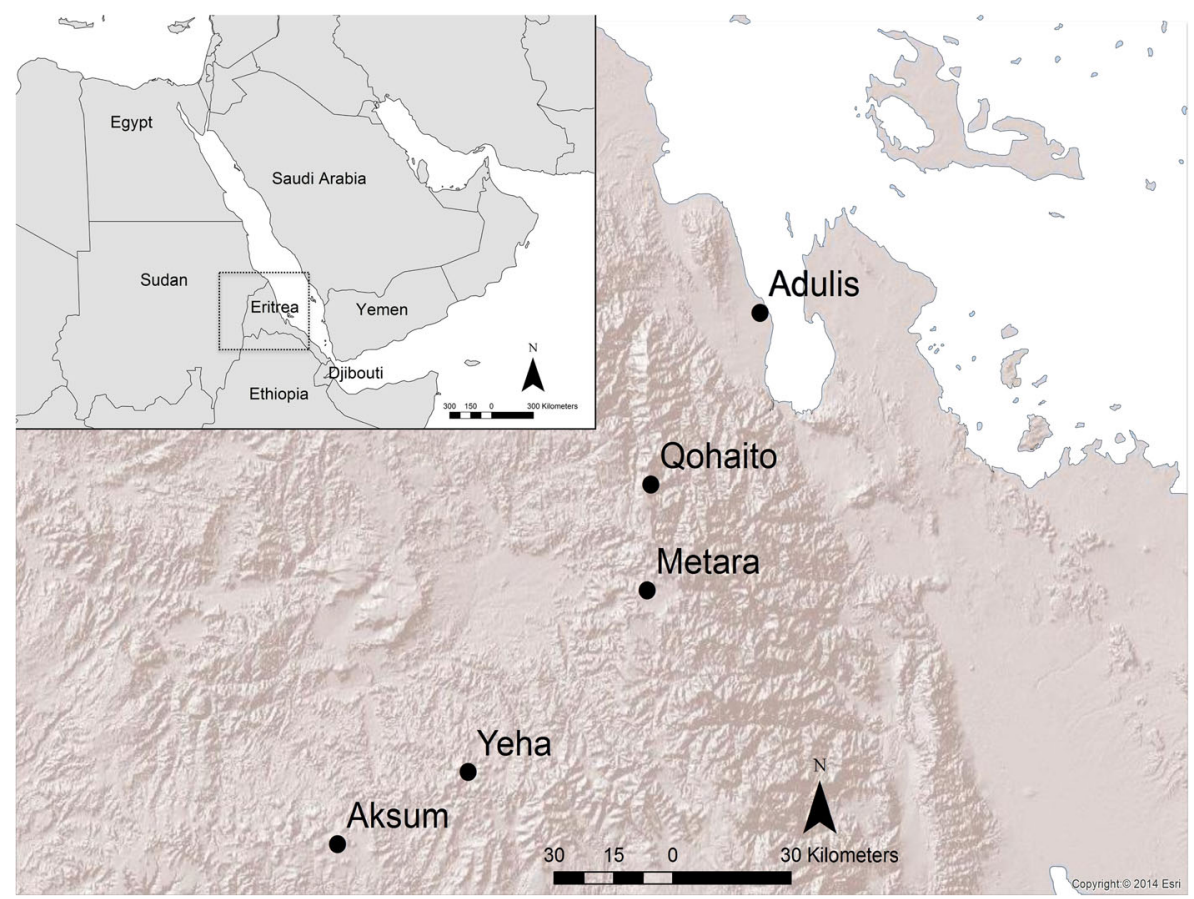

Fig. 1 Important Aksumite sites and modern geopolitical situation (inset). Map prepared by author from basemap (C) ESRI 2014, used with permission 
this time, Christianity was already firmly established and enjoyed substantial imperial support in the Roman Empire but had not yet acquired the position as state religion that it would later assume.

This article aims to situate the introduction of Christianity to the Aksumite kingdom within the context of maritime connections with the Red Sea and Western Indian Ocean. Africanist discourse on conversion has revolved around Robin Horton's model of a traditional African cosmology centered on local communities-microcosms, coming into contact with monotheistic religion of the wider world, and the macrocosm, by means of elite members acting on a trans-regional level, e.g., in connection with long-distance trade or warfare (Horton 1971, 1975a, b). Without making conjectural conclusions about the existence of a uniform traditional African cosmology or its application to the imperfectly known pre-Christian Aksumite religion, the relevance of Horton's model to the Aksumite case is clear and has been eloquently argued by Steven Kaplan $(1982,2004)$. The role of merchants in the conversion process has also been pointed out (Cerulli 1971, p. 115, n. 111; Kaplan 1982, 2004). Here, the case for a connection between trade and religion will be developed by suggesting a model of how the external stimuli of trade and maritime activities might have contributed to the internal process of conversion modeled by Horton and described by Kaplan and other scholars of Aksum. While not questioning the notion of a top-down and gradual conversion process, the aim is to nuance this understanding by surveying the regional religious landscape. The argument is made that Christianity was well established in the Red Sea region by the second quarter of the fourth century, thus creating the social infrastructure that expatriate believers, early converts, and later also church officials could draw upon.

\section{The Evidence for Conversion}

The most famous account of the origins of Christian religion in the Aksumite kingdom is from the early fifth-century church-historian Rufinus of Aquileia (Amidon 1997). Rufinus' narrative, which is echoed in the later Ge'ez account of the Synaxarium of the Ethiopian church (Budge 1928, pp. 1164-1165), relates the story of two young boys, Frumentius and Aedesius, who had been accompanying their teacher on a voyage to India, undertaken in order to study the philosophy of this country. During the return journey, the ship put in at a port to replenish its water supplies. No mention is made of Aksum in the text. In late antiquity, "India" when used by Greek and Latin authors could refer to either East Africa, South Arabia, or the Indian subcontinent (Mayerson 1993), but the purpose of the trip and the need to replenish water supplies likely point towards a long sea journey; it could indicate that peninsular India may have been the goal of the journey and that the port was in the Red Sea. More substantially, a later reference to Frumentius as the bishop of Aksum in a letter dated ca. CE 353 (Schaff 1995, pp. 702-703) also supports that the events took place in the Aksumite kingdom. Returning to the narrative of Rufinus, the existing truce between the Romans and the local rulers had been suspended, the ship was attacked, and the boys were taken as slaves. Due to their proficiency in Greek, both boys were employed at court, Aedesius acting as cupbearer and Frumentius as steward to the underage king. During his captivity, Frumentius worked to improve the conditions of Christians in the kingdom, securing rights of assembly and facilitating the construction of houses of worship. 
Upon reaching majority, the king granted the now grown-up Frumentius and Aedesius their freedom. Aedesius went back to his native Tyre in present-day Lebanon, while Frumentius left only temporarily for Alexandria. There he received the blessing of the patriarch and returned as the first bishop of the Ethiopian church (Amidon 1997, pp. 18-20).

There is no way to establish the veracity of Rufinus' narrative in detail. As church histories go, however, this is a relatively dependable one. It is written perhaps 70 80 years after the reported events, at a time when there might still have been an oral tradition to draw on that Rufinus' account could be measured against. Rufinus explicitly mentions the eye-witness Aedesius as his authority (Amidon 1997, p. 20). The narrative contains no miraculous or supernatural elements. More significant perhaps is the abovementioned letter, cited in the Apologia ad Constantium Imperatorem of Athanasius, bishop of Alexandria 328-373. Athanasius was in exile at the time (ca. 353), because he was opposed to the theological line of emperor Constantius II (337361), who had strong leanings towards Arianism. In the letter, which is addressed from Constantius to the princes of Aksum, Ezana, and his brother Sazana, the emperor calls for the extradition of Frumentius so that he can present himself to the Arian bishop George of Alexandria (Athanasius' replacement). This is in order to make sure that he was theologically acceptable to the new ecclesiastical regime in Constantinople and Alexandria, and the letter voices concern with Frumentius in this respect, as he was appointed bishop of Aksum by the exiled Athanasius (Schaff 1995, pp. 702-703).

The narrative of Rufinus, moreover, is closely paralleled in the coinage of Aksumite king Ezana, whose coins show a change from the disc and crescent symbol to that of the cross. Earlier theories of multiple kings bearing the same name are now refuted; this change in official iconography and royal self-representation can hardly be explained in ways other than that of conscious conversion (Munro-Hay and Juel-Jensen 1995). The conversion process is also visible in changed royal burial practices in the capital of Aksum (Phillipson 2012, pp. 153-154), and in the gradual introduction of first monotheistic, then explicitly Christian terminology in royal inscriptions (Kaplan 1982; Bernand et al. 1991; Phillipson 2012; Bowersock 2013; Marrassini 2013). No archaeological trace has been found, however, of churches dating back to the time of Ezana, and monumental houses of worship seem to have been constructed in major centers of the kingdom only in the sixth-seventh centuries (Phillipson 2009). Phillipson (2009, pp. 29-31) argues that this reflects a two-step conversion process, with a fourthcentury adoption of Christianity by the king and the upper echelons of Aksumite society, and a later wave of missionary activity, perhaps connected with the Ethiopian tradition of the "nine saints" in the late fifth century. Below, I argue that this reconstruction remains plausible but that maritime trade and Christian merchants played a pivotal role before and during the initial fourth-century conversion.

\section{Christianity and Trade in the Red Sea and Western Indian Ocean}

Archaeological as well as literary evidence reveals that Adulis, the main Red Sea port of the Aksumite kingdom in the period of Ezana, had been involved in Red Sea exchange at least since the first century CE (Casson 1989; Peacock et al. 2004; Peacock and Blue 2007; Zazzaro 2013), although the political status of the port at that 
time is not clear. The testimony of the sixth-century traveller known as Cosmas Indicopleustes of the presence of an inscription dedicated by Ptolemy III of Egypt (ruled 246-221 BCE) in Adulis, commemorating the elephant-hunting expeditions of his father and himself (Wolska-Conus 1968; Bowersock 2013), along with recent finds of regionally produced early pottery at the site (Manzo 2010; Zazzaro and Manzo 2012), seem to indicate an even longer record of maritime contacts. In the early period, ivory from the highland areas inland of Adulis seems to have been an export of prime importance. By the time of Ezana, when Aksum had emerged as the political powerhouse of the region, court and elite life offered a market for imported prestige items, such as the Mediterranean wine amphorae and glass vessels amply attested by excavations in the ancient capital (Morrison 1989; Munro-Hay 1989; Wilding 1989; Phillipson 2012).

There are also several indications that in the course of the third century, the Aksumite kingdom assumed the role of a hub of western Indian Ocean commerce, acting as intermediary between Red Sea and Arabian Sea circuits of exchange (Warmington 1995, pp. 137-138). These indications include the strengthening of the Aksumite state (whether as a cause or as a result), evident in the issue of gold coinage from the late third century onwards (Munro-Hay and Juel-Jensen 1995), the monumentalization of burial and domestic architecture in the capital, increased royal epigraphic activity, and the temporary control of the Arabian Red Sea coast by Aksumite rulers (Phillipson 2012, pp. 203-205; Bowersock 2013). Also, from the Roman perspective, northern Red Sea ports such as Aila and Suez seem to have gained importance at the expense of more southerly sites such as Myos Hormos and Berenike in late antiquity (Ward 2007; Sidebotham 2009; Decker 2010). This would fit with a navigation pattern, where ships from Egypt no longer regularly sailed all the way to peninsular India but remained in the Red Sea, and thus did not, to the same extent, depend on the southerly winds prevalent in the southern Red Sea during the late part of the NE monsoon for their return voyage (Casson 1989, pp. 283-292; Facey 2004).

By the time of Frumentius' mission, monotheism, in the forms of Judaism as well as Christianity, was on the advance in the Red Sea and Western Indian Ocean and had already been so for a while (Robin 1980; Tomber 2007, 2008; Beaucamp et al. 2010; Seland 2012; Bowersock 2013). With regard to Christianity, Indian churches traditionally trace their origins to the first century (Tomber 2007), and the Mediterranean church-historian Eusebius reports that Christian travellers from Egypt visiting India in the late second century found that the faith was already established there (McCrindle 1979, p. 214). This seems to indicate that Christianity had arrived by way of the Persian Gulf, where Christian presence is well attested from the fourth century onwards (Atiya 1968, p. 258; Potts 1990). Late Roman churches have been excavated at all major Roman Red Sea ports (Tomber 2007, 2008; Sidebotham 2009), among them one at Aila, which has been suggested to be the oldest purpose-built church in the world yet identified (Parker 1998), predating Frumentius' activities by decades.

Bagnall estimates the percentage of Christians in Egypt at ca. 20 at the time of toleration in 313 and $c a .50$ in 337, the time of Constantine's death and near the conversion of Ezana (1996, p. 281). Rufinus' account of the conversion of Aksum lets Frumentius' work commence among the Christians already present in the kingdom (Amidon 1997, p. 19). The church history of Philostorgius relates the journey of Theophilus the Indian to churches in the Red Sea and Western Indian Ocean ca. 356 
CE (Amidon 2007, pp. 40-43). Theophilus travelled as the envoy of Constantius II, to secure that Indian Ocean churches were in line with current imperial theology. Theophilus' itinerary seems to have included peninsular India, Socotra (or possibly the Maldives), Southern Arabia, and the Aksumite kingdom (Pigulewskaja 1969, p. 73). In Southern Arabia, he especially asked for royal permission to build churches for the Roman merchant residents there (Amidon 2007, p. 40). The presence of Christianized Arab tribes in northwestern Arabia is also well documented (Shahîd 1984; Fisher 2013).

\section{Trade, Social Networks, and the Introduction of Christianity to Aksum}

With regard to Aksum, the lesson that can be inferred from this is that Christianity was not new to the region when Frumentius arrived. It seems likely, however, that in the early stages, the religion was primarily associated with people involved in maritime trade (Cerulli 1971, p. 115, n. 111; Kaplan 2004, p. 377). As mentioned, Rufinus states that Frumentius began his work among the resident Roman merchants, securing privileges of worship and sites and material support for them to build places of assembly. Only after his ordination as bishop and his return to Aksum did he start developing a local church organization and commence the conversion of the kingdom at large (Amidon 1997, pp. 18-20). This is not surprising. Travel in the ancient world was strenuous and potentially dangerous, and few people engaged in it without good purpose. There were no alternative means of transport other than merchant ships. These would accept occasional passengers (Casson 1995, pp. 180-181), such as the diplomatic envoys, travelling missionaries, philosophers, and church officials that figure in late antique literary sources, but the vast majority of Red Sea travellers would have been directly involved in trade or shipping. A telling piece of evidence for the precarious nature of Red Sea communications is an imperial edict of CE 356, prohibiting Roman envoys to Aksum and the South Arabian kingdom of Himyar from lingering more than one year in Alexandria en route (Pharr et al. 2001, p. 380). The long travel times combined with challenges of communication, credit, and cultural differences led to most long-distance trade in the ancient world being conducted by way of permanent or long-term expatriates, constituting so-called trade diasporas (Curtin 1984). Members of these trade diasporas held expertise in host and home cultures alike and could facilitate exchange between maritime and hinterland networks.

Diaspora settlements are hard to trace archaeologically, as imported goods might have been carried and consumed by local actors. As of yet, no finds have been made in the region, for instance, of imported cooking pots that have been interpreted as a proxy of resident foreign communities at Red Sea and Indian Ocean ports such as Berenike, Myos Hormos, and Khor Rori (Pavan and Schenk 2012; Tomber 2012). Nevertheless, there is good literary evidence of diaspora settlements in the region, including, besides Rufinus' account, a reference in the first-century Periplus of the Erythraean Sea to the import of coinage for the resident foreign merchants (Casson 1989, pp. 52-53).

Trade diasporas were not formal organizations but social networks, and they depended on a degree of social cohesion (Seland 2013). Common origin is a normal way of creating such "groupness" (Brubaker 2005, 2009) among people living away from home, invoking potential shared ties such as language, culture, diet, ethnicity, and 
religion. Early Indian Ocean trade shows clear indications of merchant networks based on such variables (Seland 2013). So-called portable religions, faiths that can be worshipped independently of place and primary social groups (McNeill 1987), however, have been demonstrated to be an important factor of cohesion in Indian Ocean trade networks in the cases of Buddhism (Ray 1986, 1998), Judaism (Margariti 2007; Goitein and Friedman 2008), Islam (Risso 1995), and arguably also Christianity (Seland 2012, 2013). Religion potentially combines open access to the social network for adherents with strong solidarity among members, especially in minority situations such as that experienced by Christians in the Aksumite kingdom before the conversion. Christians will have had limited access to the social networks of polytheistic compatriots as well as local inhabitants, because of normative restrictions on taking part in communal meals and offerings. This will have fostered strong solidarity within the community and corresponding receptivity to Frumentius' support for initiatives of church building and freedom of assembly.

What needs to be highlighted, however, is that the initial introduction of Christianity to the Aksumite kingdom did not come as a result of church initiatives or missions from the Roman Empire but as a result of the nodal role that the kingdom played in third- to fourth-century Indian Ocean trade. Traders meeting in Aksumite ports would come from, be returning from, or be on their way to places such as Socotra, South Arabia, Malabar, and the Persian Gulf, where we know from earlier or contemporary accounts that Christian churches were in operation, and places such as northwestern India and Sri Lanka, where it is very likely that there were also Christian communities. This early influx of Christianity to Aksum - the Christian merchants among whom Frumentius started his work - took place outside official church channels, and in a religious landscape before the standardization of religious doctrine following the council of Nicaea (CE 325), the Arian controversy during the rule of Constantius, and the schism between the Eastern and the Western Church in CE 431. We should therefore expect that these early Christian networks were relatively open and flexible towards coreligionists of different geographical origins and theological leanings. Indeed, the effort to bring Indian Ocean churches in line with Roman imperial religious policy visible in the letter to Ezana and the journey of Theophilus seems to indicate a preexisting situation of Christian polyphony.

A critical point in Rufinus' narrative is that with regard to the building of churches for Roman merchants, the plural is used throughout in the Latin text (Schwartz and Mommsen 1999). This implies that Christian individuals, increasingly able to form communities as a result of Frumentius' support, would be present not only in the port of trade of Adulis but also in multiple centers of the kingdom. Rufinus' account on this point cannot be independently confirmed, but is plausible in light of the substantial number of archaeologically documented sites of urban nature in the Aksumite core region (Michels 1988, 2005; Phillipson 2012), and the fact that ivory, the primary export from the kingdom, as well as consumption and population centers were situated in the highlands. If correct, this implies that trade networks and thus the social networks of Christian traders did not only intersect with Aksumite society in the port city of Adulis but also in multiple locations across the kingdom.

Modern sociological studies of conversion processes stress that they never happen in a vacuum and by mass conversion, but evolve gradually along social networks. People convert because their friends, colleagues, or family members have already done so 
(Stark and Bainbridge 1980; Stark 2012). Frumentius' success in eventually establishing an Aksumite church and in bringing about the conversion of Ezana should be ascribed to his access to two such networks and the ability to tap into a third. The first network was that of Christian merchants taking part in Indian Ocean trade, which was there before Frumentius arrived but that he helped strengthen by arranging for privileges and material support. The second network was the Aksumite elite that he became part of due to his position at the court. This elite will have become familiar with Christian religion through their long-term and regular exposure to the faith by Frumentius and Aedesius, who over time became respected elite members themselves. With regard to the Aksumite elite, it also seems significant that there was a longstanding ideological tie to the Mediterranean world, visible in the use of Greek language in inscriptions and coin legends, and the adoption of Roman weight standards for coinage (Munro-Hay and Juel-Jensen 1995, but see Phillipson 2012, p. 183). This tradition might also have influenced the receptiveness to changes in the Mediterranean religious landscape. The third network was that of the official church hierarchy, which Frumentius linked up to after his release from slavery, and that enabled him to return as a bishop in charge of establishing a local church organization. This network perspective, however, also implies that Ezana's acceptance of the new faith was only the start of the conversion of the Aksumite population on a larger scale. Stark has suggested a $3.4 \%$ annual growth rate for the first three centuries of Mediterranean Christianity, leading to a Christian majority in the Roman empire by the mid-fourth century (Stark 2012). Such figures are of course very approximate, and there are no data that allow us to transfer them to an Aksumite setting. Nevertheless, they show the potential of slow and gradual conversion processes to have tremendous impact over time if they are not halted by external factors. This is entirely consistent with the absence of monumental church buildings in Aksumite urban centers before the sixth-seventh centuries (Phillipson 2009), with Phillipson's observation that monotheism is more visible in Greek than in Ge'ez texts of the early period, and with the Ethiopian tradition of the important role of the so-called nine saints in spreading Christianity in rural areas and founding monasteries and churches in the late fifth century (Phillipson 2012, pp. 104 105). Coinage, on the other hand, where Christian symbolism is taken up from the start, was primarily a medium for communicating with trade partners, elites, soldiers, and other recipients of royal payments and thus a way to promote the new religion to foreign and domestic elite networks.

\section{Conclusion}

The argument of this short article is that the introduction of Christianity to East Africa should be interpreted in light of maritime trade. Christianity was established on all coasts of the Red Sea and Western Indian Ocean well ahead of the official adoption of the faith by the Aksumite kings. Trade facilitated the spread of religion, in the first place not so much because of missionaries and church officials but because Christian merchants constituted social networks that met their need for social security and solidarity, in situations where they operated far from their homes and under considerable risk for prolonged periods of time. When Frumentius started his missionary work in Aksum, his first target was the already existing resident Christian diaspora. He then 
continued within the elite network that he himself had become part of and by linking up with the Mediterranean church organization. This does not challenge the scholarly consensus of Aksumite conversion as a top-down process, and the important role played by individuals such as Frumentius and Ezana, but nuances the picture by drawing attention to the point of departure for this process, without which it would probably not have taken place. This interpretation is also in line with recent scholarship on the spread of Christianity in the Mediterranean world, emphasizing the role of social networks and gradual conversions over lone missionaries and mass conversions (Stark and Bainbridge 1980; Stark 2012) and with Horton's model of African conversion processes in more recent periods (Horton 1971, 1975a, b; Kaplan 1982, 2004).

Christianity continued to thrive in the Indian Ocean beyond the end of the Aksumite period, and the continued influence of Red Sea and Indian Ocean Christianity on the Aksumite church is a subject that should clearly be considered along with the important links to Egypt and Christian Nubia that are traditionally emphasized.

Acknowledgments This research was funded by the Norwegian Research Council SAMKUL initiative under the project Mechanisms of cross-cultural interaction: Networks in the Roman Near East (Project No. 220868/F10). Thanks to Professor Emeritus Richard Holton Pierce, the editor and reviewers of African Archaeological Review for their input and advice, and Ms. Katia Schörle for translating the abstract into French.

Open Access This article is distributed under the terms of the Creative Commons Attribution License which permits any use, distribution, and reproduction in any medium, provided the original author(s) and the source are credited.

\section{References}

Amidon, P. R. (1997). The church history of Rufinus of Aquileia, books 10 and 11. New York: Oxford University Press.

Amidon, P. R. (2007). Philostorgius: Church history. Atlanta: Society of Biblical Lit.

Atiya, A. S. (1968). A history of Eastern Christianity. London: Methuen.

Bagnall, R. S. (1996). Egypt in late antiquity. Princeton: Princeton University Press.

Beaucamp, J., Briquel-Chatonnet, F., \& Robin, C. J. (2010). Juifs et chrétiens en Arabie aux Ve et Vle siècles: Regards croisés sur les sources. Paris: ACHCByz.

Bernand, E., Drewes, A. J., \& Schneider, R. (Eds.). (1991). Recueil des inscriptions de l'Éthiopie des périodes pré-axoumite et axoumite (2 vols). Paris: Académie des Inscriptions et Belles-Lettres.

Bowersock, G. W. (2013). Throne of Adulis: Red Sea wars on the eve of Islam. Oxford: Oxford University Press.

Brubaker, R. (2005). The 'diaspora' diaspora. Ethnic and Racial Studies, 28(1), 1-19.

Brubaker, R. (2009). Ethnicity, race, and nationalism. Annual Review of Sociology, 35, 21-42.

Budge, E. A. W. (1928). The Book of the Saints of the Ethiopian Church: A translation of the Ethiopic synaxarium made from the manuscripts Oriental 660 and 661 in the British Museum. Cambridge: Cambridge University Press.

Casson, L. (1989). The Periplus Maris Erythraei. Princeton: Princeton University Press.

Casson, L. (1995). Ships and seamanship in the ancient world. Baltimore and London: Johns Hopkins University Press.

Cerulli, E. (1971). L'Islam di ieri e di oggi. Roma: Istituto per l'Oriente.

Conti Rossini, C. (1928). Storia d'Etiopia. Milano: Officina d'arte grafica A. Lucini.

Curtin, P. D. (1984). Cross-cultural trade in world history. Cambridge: Cambridge University Press.

Decker, M. (2010). Settlement and trade in the Red Sea in late antiquity: An archaeological perspective. Ancient West and East, 9, 193-220. 
Facey, W. (2004). The Red Sea: The wind regime and location of ports. In P. Lunde \& A. Porter (Eds.) Trade and travel in the Red Sea region: Proceedings of the Red Sea Project I. Held in the British Museum October 2002 (pp. 7-17). Oxford: Archaeopress.

Fisher, G. (2013). Between empires: Arabs, Romans, and Sasanians in Late Antiquity. Oxford: Oxford University Press.

Goitein, S. D., \& Friedman, M. A. (2008). India traders of the Middle Ages: Documents from the Cairo Geniza India book. Leiden: Brill.

Haas, C. (2008). Mountain Constantines: The Christianization of Aksum and Iberia. Journal of Late Antiquity, 1(1), 101-126.

Horton, R. (1971). African conversion. Africa, 41(2), 85-108.

Horton, R. (1975a). On the rationality of conversion. Part I. Africa, 45(3), 219-235.

Horton, R. (1975b). On the rationality of conversion. Part II. Africa, 45(4), 373-399.

Kaplan, S. (1982). Ezana's conversion reconsidered. Journal of Religion in Africa, 13(2), 101-109.

Kaplan, S. (2004). Themes and methods in the study of conversion in Ethiopia: A review essay. Journal of Religion in Africa, 34(3), 373-392.

Manzo, A. (2010). Adulis before Aksum? Possible 2nd and 1st millenium BC evidence from the site of the ancient port. $A I O N, 70,29-42$.

Margariti, R. E. (2007). Aden \& the Indian Ocean trade: 150 years in the life of a medieval Arabian port. Chapel Hill: University of North Carolina Press.

Marrassini, P. (2013). Lord of heaven. Rassegna di Studi Etiopici, 4, 103-117.

Mayerson, P. (1993). A confusion of Indias: Asian India and African India in the Byzantine sources. Journal of the American Oriental Society, 113(2), 169-174.

McCrindle, J. W. (1979 [1901]). Ancient India as described in Classical literature. New Delhi: Oriental Books Reprint Corporation.

McNeill, W. (1987). The era of civilizations in world history. Newsletter of the World History Association, $4(1), 1-4$.

Michels, J. W. (1988). The Axumite Kingdom-A settlement archaeology perspective. In Proceedings of the Ninth International Congress of Ethiopian Studies (Vol. 1, pp. 173-183). Moscow: USSR Academy of Science.

Michels, J. W. (2005). Changing settlement patterns in the Aksum-Yeha region of Ethiopia: 700 BC-AD 850. Oxford: Archaeopress.

Morrison, H. M. (1989). The glass. In S. Munro-Hay (Ed.), Excavations at Aksum: An account of research at the ancient Ethiopian capital directed in 1972-4 by the late Dr Neville Chittick. London: The British Institute in Eastern Africa.

Munro-Hay, S. (1989). Excavations at Aksum: An account of research at the ancient Ethiopian capital directed in 1972-4 by the late Dr. Neville Chittick. London: The British Institute in Eastern Africa.

Munro-Hay, S. (1991). Aksum - An African civilisation of late antiquity. Edinburgh: Edinburgh University Press.

Munro-Hay, S., \& Juel-Jensen, B. (1995). Aksumite coinage. London: Spink.

Parker, S. T. (1998). An early church, perhaps the oldest in the world, found at Aqaba. Near Eastern Archaeology, 61(4), 254.

Pavan, A., \& Schenk, H. (2012). Crossing the Indian Ocean before the Periplus: A comparison of pottery assemblages at the sites of Sumhuram (Oman) and Tissamaharama (Sri Lanka). Arabian Archaeology and Epigraphy, 23(2), 191-202.

Peacock, D., \& Blue, L. (Eds.). (2007). The ancient Red Sea port of Adulis, Eritrea. Report of the EritroBritish Expedition, 2004-2005. Oxford: Oxbow.

Peacock, D., Blue, L., Gebreyesus, Y., \& Habtemichael, D. (2004). The Eritreo-British Project at Adulis, Interim Report 2004. Asmara and Southampton.

Pharr, C., Davidson, T. S., \& Pharr, M. B. (2001). The Theodosian code and novels and the Sirmondian constitutions: A translation with commentary, glossary, and bibliography. Princeton: Princeton University Press.

Phillipson, D. W. (2009). Ancient churches of Ethiopia: Fourth-fourteenth centuries. New Haven: Yale University Press.

Phillipson, D. W. (2012). Foundations of an African civilization: Aksum and the Northern Horn, 1000 BC1300 AD. Oxford: James Currey.

Pigulewskaja, N. (1969). Byzanz auf den Wegen Nach Indien: Aus der Geschichte des bysantinischen Handels mit dem Orient vom 4. bis 6. Jahrhundert. Berlin: Akademie Verlag.

Potts, D. T. (1990). The Arabian Gulf in antiquity. Oxford: Oxford University Press.

Ray, H. P. (1986). Monastery and guild: Commerce under the Satavahanas. Delhi: Oxford University Press. 
Ray, H. P. (1998). The winds of change - Buddhism and the maritime links of early South Asia. Delhi: Oxford University Press.

Risso, P. (1995). Merchants and faith: Muslim commerce and culture in the Indian Ocean. Boulder: Westview Press.

Robin, C. (1980). Judaïsme et christianisme en Arabie du Sud d'après les sources épigraphiques et archéologiques. Proceedings of the Seminar for Arabian Studies, 10, 85-96.

Schaff, E. J. (1995). Athanasius: Select works and letters. Peabody, MA: Hendrickson Publishers (Original edition 1890-1900).

Schwartz, E., \& Mommsen, T. (1999). Die Kirchengeschichte (Vol. 2. Bd 2.). Berlin: Akademie-Verlag.

Seland, E. H. (2012). Trade and Christianity in the Indian Ocean during late antiquity. Journal of Late Antiquity, 5(1), 72-86.

Seland, E. H. (2013). Networks and social cohesion in ancient Indian Ocean trade: Geography, ethnicity, religion. Journal of Global History, 8(3), 373-390.

Shahîd, I. (1984). Byzantium and the Arabs in the fourth century. Washington, DC: Dumbarton Oaks.

Sidebotham, S. E. (2009). Northern Red Sea ports and their networks in the late Roman/Byzantine period. In M. M. Mango (Ed.), Byzantine trade, 4th-12th centuries (pp. 329-352). Farnham: Ashgate.

Stark, R. (2012). The triumph of Christianity: How the Jesus movement became the world's largest religion. London: Harper Collins.

Stark, R., \& Bainbridge, W. S. (1980). Networks of faith: Interpersonal bonds and recruitment to cults and sects. American Journal of Sociology, 1376-1395.

Tomber, R. (2007). Bishops and traders: The role of Christianity in the Indian Ocean during the Roman period. In J. Starkey, P. Starkey, \& T. Wilkinson (Eds.), Natural resources and cultural connections of the Red Sea (pp. 219-226). Oxford: Archaeopress.

Tomber, R. (2008). Indo-Roman trade, from pots to pepper. London: Duckworth.

Tomber, R. (2012). From the Roman Red Sea to beyond the empire: Egyptian ports and their trading partners. British Museum Studies in Ancient Egypt and Sudan, 18, 201-215.

Ward, W. (2007). Aila and Clysma: The rise of northern ports in the Red Sea in late antiquity. In J. Starkey, P. Starkey, \& T. Wilkinson (Eds.), Natural resources and cultural connections of the Red Sea (pp. 161-171). Oxford: Archaeopress.

Warmington, E. H. (1995 [1928]). The commerce between the Roman Empire and India. New Delhi: Munshiram Manoharlal.

Wilding, R. F. (1989). The pottery. In S. Munro-Hay (Ed.), Excavations at Aksum (pp. 235-316). London: The British Institute in Eastern Africa.

Wolska-Conus, W. (1968). Cosmas Indicopleustes: Topographie Chrétienne. Paris: Cerf.

Zazzaro, C. (2013). The ancient Red Sea port of Adulis and the Eritrean coastal region: Previous investigations and museum collections. Oxford: Archaeopress.

Zazzaro, C., \& Manzo, A. (2012). A preliminary assessment on the pottery assemblage from the port town of Adulis (Eritrea) (in collaboration with G. Teklemariam, M. Tabo Sium, and T. Tesfagiyorgis Paulos). British Museum Studies in Ancient Egypt and Sudan, 18, 233-246. 